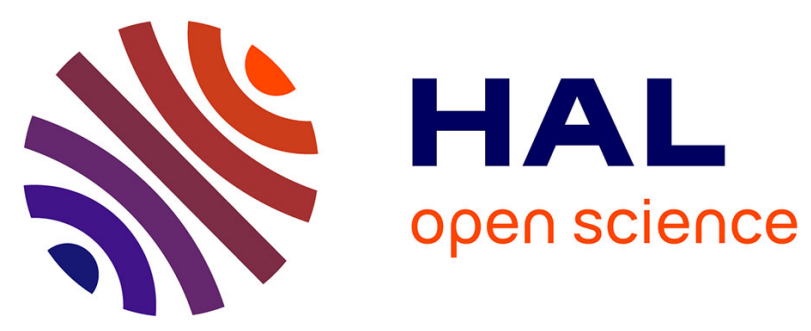

\title{
AN EELS STUDY OF THE INTRANUCLEAR INCLUSIONS OF THE EPIDIDYMIS PRINCIPAL CELLS IN THE GARDEN DORMOUSE, ELIOMYS QUERCINUS L.
}

\author{
F. Hawkes, Yolande Kihn, Jean Sévely
}

\section{To cite this version:}

F. Hawkes, Yolande Kihn, Jean Sévely. AN EELS STUDY OF THE INTRANUCLEAR INCLUSIONS OF THE EPIDIDYMIS PRINCIPAL CELLS IN THE GARDEN DORMOUSE, ELIOMYS QUERCINUS L.. Journal de Physique Colloques, 1984, 45 (C2), pp.C2-585-C2-586. 10.1051/jphyscol:19842134 . jpa-00223804

HAL Id: jpa-00223804 https://hal.science/jpa-00223804

Submitted on 1 Jan 1984

HAL is a multi-disciplinary open access archive for the deposit and dissemination of scientific research documents, whether they are published or not. The documents may come from teaching and research institutions in France or abroad, or from public or private research centers.
L'archive ouverte pluridisciplinaire HAL, est destinée au dépôt et à la diffusion de documents scientifiques de niveau recherche, publiés ou non, émanant des établissements d'enseignement et de recherche français ou étrangers, des laboratoires publics ou privés. 


\title{
AN EELS STUDY OF THE INTRANUCLEAR INCLUSIONS OF THE EPIDIDYMIS
} PRINCIPAL CELLS IN THE GARDEN DORMOUSE, ELIOMYS QUERCINUS L.

\author{
F. Hawkes, Y. Kihn and J. Sevely
}

Laboratoire d'optique Electronique du $\mathrm{CNRS}^{+}$, 29 me Jeanne Marvig, 3.1400 Toulouse, France

Résumé : Les inclusions intranucléaires des cellules principales de l'êpididyme du lērot contiennent $\mathrm{C}, \mathrm{N}, \mathrm{O}, \mathrm{Mg}, \mathrm{P}$, $\mathrm{S}$ et $\mathrm{Fe}$.

Abstract : In the intranuclear inclusions of the epididymis principal cells of the garden dormouse, $\mathrm{C}, \mathrm{N}, 0, \mathrm{Mg}, \mathrm{P}, \mathrm{S}$ and $\mathrm{Fe}$ are found.

Hammar was the first to report, in 1897 , globular inclusions in the nuclei of the columnar epithelial cells lining the ductus epididymidis. He observed them in the dog where they are very abundant. They are also present in man and in the stallion but are absent from. sheep, cat, rabbit guinea pig, rat and mouse. We have now found them in an ascrotal hibernator, the garden dormouse, Eliomys quercinus L., but we have been unable to detect them in another hibernator, this time a scrotal mammal, the thirteen-lined ground quirrel spermophilus tridecemlineatus.

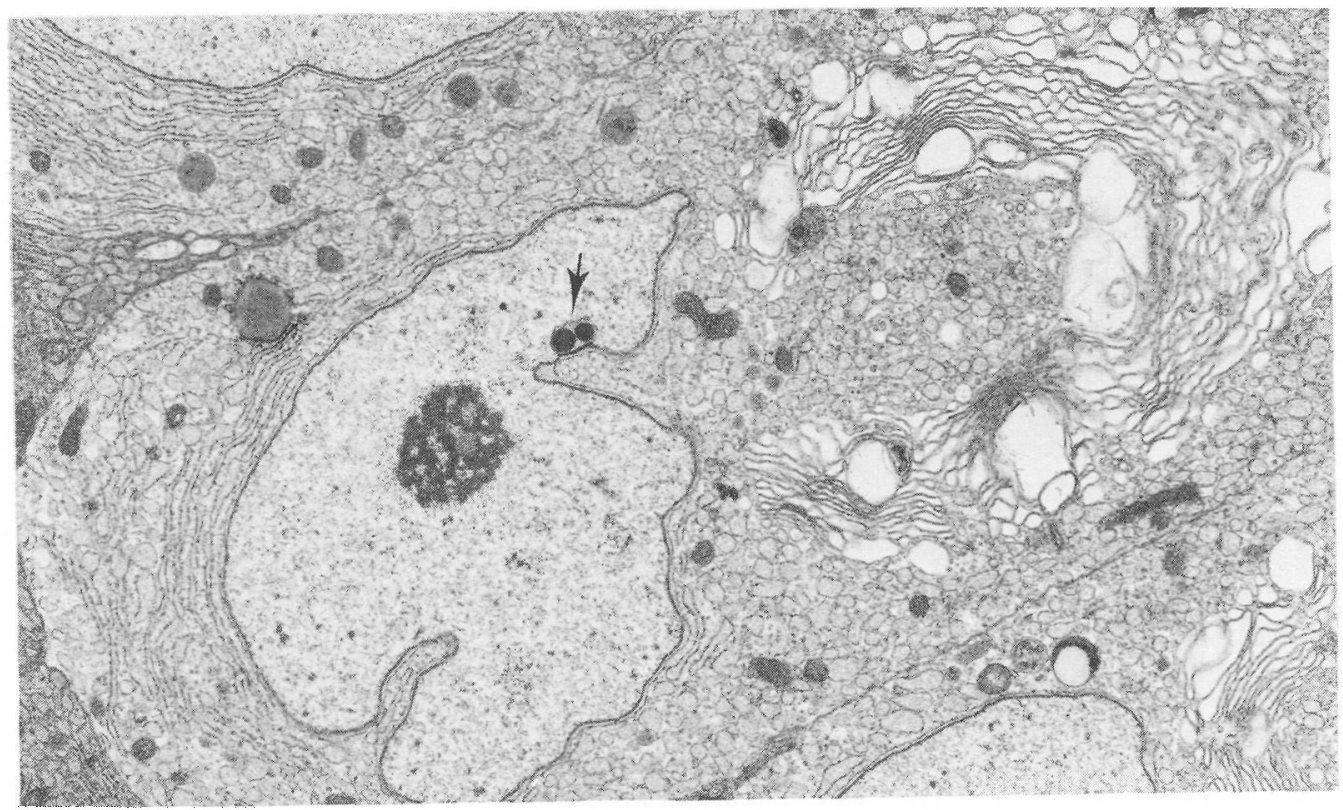

Epididymis principal cell. The nuclear inclusions (arrow) are globular. $\times 8,000$.

\footnotetext{
+associé à 1'Université Paul Sabatier
} 
The granules are found in the perinuclear space before their passage into the nucleus It seems that the endoplasmic reticulum sacculae which stock them after their synthesis, fuse with the outer nuclear envelope. Indeed, many of our observations have shown a continuity between the cisternal lumen and the perinuclear space. The granule are then invested by the inner membrane of the nuclear envelope and transferred into the nucleus. They later disintegrate into a finely particulate material and the vacuole is finally left with an electron transparent content.

The number of intranuclear inclusions varies with the hormonal state of the animal. A careful study over four years in which several animals were examined each month leads us to conclude that the granules are always present just before a rise in plasma testosterone; they are found in January, June and September.

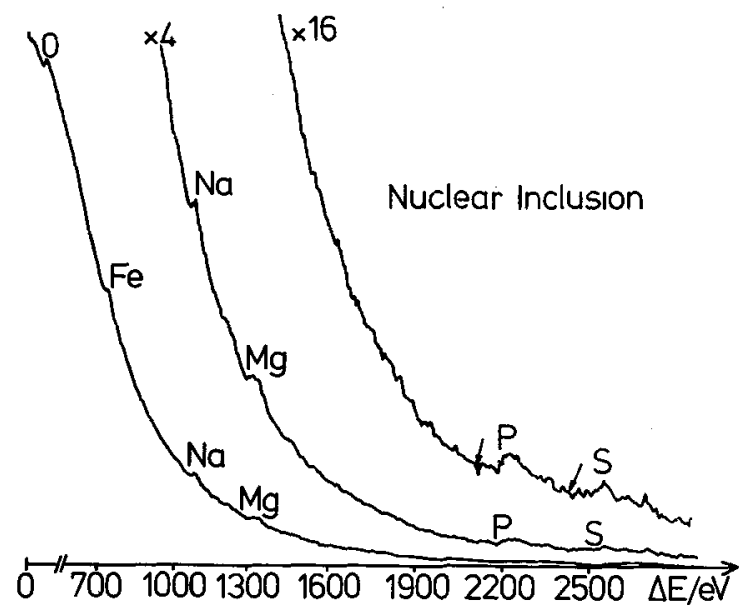

EELS analysis of a nuclear inclusion.

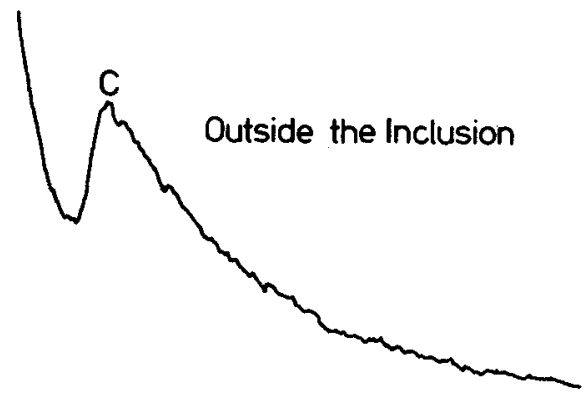

Outside of the nuclear inclusion.

The EELS analyses were performed with an $\Omega$-filter fitted to the Toulouse $1.2 \mathrm{MN} \mathrm{mi-}$ croscope. We worked at 1 MV. The selected areas were about $100 \mathrm{~nm}$ in diameter and we were, therefore, always analysing only the granules. The spectra were traced with a Tracor $\mathrm{TN}-11$. We detected $\mathrm{C}, \mathrm{N}, 0$; $\mathrm{Mg}$ was identified by its $\mathrm{K}$ line at $1305 \mathrm{eV}$, P by that at $2140 \mathrm{eV}, \mathrm{S}$ by that at $2470 \mathrm{eV}$; Fe was identified by its L23 1ine at $730 \mathrm{eV}$. This suggests that the granules are made of protein associated with phosphorus, sulphur, iron and magnesium. 